\author{
MiRosŁaW WójTOWICZ \\ Uniwersytet Pedagogiczny w Krakowie, Polska \\ Pedagogical University of Cracow, Poland
}

\title{
Rola przemysłu samochodowego w rozwoju społeczno-gospodarczym Meksyku
}

\section{The Role of the Automotive Industry in the Socio-Economic Development of Mexico}

\begin{abstract}
Streszczenie: Artykuł ma na celu zbadanie zmian znaczenia przemysłu samochodowego w rozwoju społeczno-gospodarczym Meksyku, ze szczególnym uwzględnieniem 16 stanów, w których koncentruje się jego działalność. W analizie uwzględniono okres od połowy lat osiemdziesiątych XX wieku do ostatniego spisu przemysłowego w 2014 roku. W tym czasie zaszły zasadnicze zmiany w polityce rządu względem tego sektora, zrywające ze strategią jego rozwoju na bazie rynku wewnętrznego na korzyść zwiększania produkcji eksportowej. W celu określenia znaczenia sektora motoryzacyjnego w poszczególnych stanach wzięto pod uwagę wielkość zatrudnienia oraz udział w wartości dodanej brutto (WDB). Przeprowadzone badania pozwoliły stwierdzić, iż wraz ze zmianą międzynarodowych i krajowych uwarunkowań rozwoju przemysłu samochodowego, prowadzących do zmian w jego przestrzennym rozmieszczeniu, odegrał on bardzo ważną rolę w rozwoju społeczno-gospodarczym stanów będących w ostatnich dwóch dekadach miejscami nowych inwestycji związanych z tym sektorem. Równocześnie zmniejszyło się jego znaczenie w rozwoju tych stanów, w których zlokalizowane były zakłady w początkowej fazie jego rozwoju.
\end{abstract}

\begin{abstract}
The aim of this paper is to determine the evolution of the position of the automobile industry in the socio-economic development of Mexico, with particular focus on 16 states, which concentrates its main activities. The analysis included the period from the mid 1980s to the last industrial census in 2014. During this period, there was a significant change in government policy towards the sector, breaking with the strategy of its development based on the internal market in favour of increasing export production. In order to determine the importance of the automotive sector in analysed states the changes in the level of employment and share in the gross value added (GVA) were taken into account. The study led to the conclusion that with the change of international and domestic conditions of the development of the automotive industry, which led to changes in the spatial distribution, this industry has played a very important role in socio-economic development of these Mexican states which in the past two decades were places of new investments in this sector. At the same time automotive sector decreased its importance in the development of these states, where the plants were located in the initial phase of its development.
\end{abstract}

Słowa kluczowe: Meksyk; przemysł samochodowy; rozwój regionalny; rozwój społeczno-gospodarczy Keywords: automotive industry; Mexico; regional development; socio-economic development 
Otrzymano: 15 stycznia 2017

Received: 15 January 2017

Zaakceptowano: 31 lipca 2017

Accepted: 31 July 2017

\section{Sugerowana cytacja / Suggested citation:}

Wójtowicz, M. (2017). Rola przemysłu samochodowego w rozwoju społeczno-gospodarczym Meksyku. Prace Komisji Geografii Przemysłu Polskiego Towarzystwa Geograficznego, 31(4), 83-102. https://doi. org/10.24917/20801653.314.6

\section{WSTĘP}

Od początku rewolucji przemysłowej sektor motoryzacyjny zaczął odgrywać coraz ważniejszą rolę w rozwoju społeczno-gospodarczym. Duże zróżnicowanie działalności przemysłowej sprawia, iż pełni ona liczne funkcje społeczno-gospodarcze. Najważniejsza z nich związana jest z produkcją dóbr inwestycyjnych dla gospodarki, przez co staje się także źródłem innowacji i inspiruje rozwój nowych technologii oraz sposobów organizacji. Wdrażanie innowacji może prowadzić do spadku kosztów produkcji, a także kreować nowe produkty oraz związany z nimi popyt inwestycyjny i konsumpcyjny. Znaczenie niektórych inwestycji jest często tak wielkie, że ich wprowadzenie określa się mianem „rewolucji przemysłowej”, mającej kluczowe znaczenie dla dalszego rozwoju społeczno-gospodarczego. Rola części wynalazków i innowacji przemysłowych wskazuje, iż przemysł pełni także funkcję cywilizacyjną, zmieniając sposób funkcjonowania całych społeczeństw. W tym miejscu warto również wspomnieć o społecznej funkcji przemysłu, polegającej na zapewnieniu miejsc pracy i dochodów dla ludności, podniesieniu poziomu edukacji i umiejętności technicznych, co w dłuższym okresie czasu prowadzi do zmiany stylu życia ludności, głównie poprzez przyspieszenie procesów urbanizacji. Poszukując odpowiedzi na pytanie o rolę przemysłu w rozwoju społeczno-gospodarczym, należy też zwrócić uwagę na funkcję ekonomiczną tego sektora, związaną z dostarczaniem dochodów budżetowych oraz wpływów z eksportu wytwarzanych towarów (Galbraith, 1973; Acemoglu, Robinson 2014).

Spośród różnych działalności przemysłowych szczególnie ważny dla rozwoju społeczno-gospodarczego państw, począwszy od końca XIX wieku aż do współczesności, wydaje się być sektor motoryzacyjny (Altshuler, Anderson, Jones, Roos, Womack, 1986; Womack, Jones, Roos, 2007; Łasak, 2013). Przemysł samochodowy odgrywał szczególnie ważną rolę w procesie industrializacji i rozwoju społeczno-gospodarczym państw rozwijających się, takich jak Meksyk, w których ze względu na niedostatek kapitału i technologii sektor ten rozwinął się głównie dzięki inwestycjom dużych koncernów międzynarodowych (Bennett, Sharpe, 1984; 1985). Liczne powiązania z innymi gałęziami przemysłu, a także z niektórymi sektorami usług, sprawiają, iż przemysł samochodowy może kreować ważny impuls rozwojowy i modernizacyjny zarówno społeczeństwa, jak i całej gospodarki. Natomiast przekształcenia zachodzące w tym sektorze, wynikające ze zmian technologicznych, ale także będące efektem procesów globalizacji i regionalizacji światowej gospodarki, dodatkowo modyfikują jego funkcjonowanie w poszczególnych krajach (Carrillo, 1991; 2000; 2004; Czerny, 1994; Moreno-Brid, 1996; Moreno-Brid, Santamaria, Rivas Valdivia, 2005; Miranda, 2007; Covarrubias, 2011).

Celem pracy jest próba określenia roli przemysłu samochodowego w rozwoju społeczno-gospodarczym Meksyku. Szczególną uwagę poświęcono zatrudnieniu w tym 
sektorze, starając się z jednej strony określić zmiany ogólnej jego wielkości, ale z drugiej zbadać także, czy zaszły jakieś zmiany w regionalnym rozkładzie zatrudnienia, czy dochodzi do jego większego przestrzennego rozproszenia i aktywizacji obszarów, na których wcześniej przemysł ten był nieobecny. Przeprowadzone badania zmierzały także do odpowiedzi na pytanie, jak zmienił się udział poszczególnych stanów w wartości dodanej oraz eksporcie sektora motoryzacyjnego. Celem badań była weryfikacja hipotezy mówiącej, że wraz ze zmianą strategii rozwoju tego sektora, polegającej na odejściu od produkcji tylko na wewnętrzny rynek i coraz większym znaczeniu eksportu, która dodatkowo została wzmocniona poprzez integrację Meksyku w ramach NAFTA, doszło do przesunięcia się zatrudnienia i działalności produkcyjnej do stanów leżących bliżej granicy ze Stanami Zjednoczonymi.

Realizacja tak postawionych celów oraz weryfikacja przyjętej hipotezy zdeterminowały układ dalszej części pracy. W pierwszym podrozdziale przeanalizowano zmiany meksykańskiej polityki w stosunku do sektora motoryzacyjnego od lat sześćdziesiątych XX wieku do 2014 roku oraz ich wpływ na sytuację tego sektora. W tej części pracy uwzględniono także globalne zmiany zachodzące w przemyśle samochodowym oraz ich wpływ na sytuację tego sektora w Meksyku. W kolejnym podrozdziale zbadano przemiany w wielkości i regionalnym rozmieszczeniu zatrudnienia oraz wartości dodanej brutto w przemyśle samochodowym od połowy lat osiemdziesiątych XX wieku do 2014 roku, co pozwoliło określić skalę i kierunki regionalnych przesunięć, jakie dokonały się $\mathrm{w}$ tym sektorze w badanym okresie. W celu pełnego zobrazowania zmian w rozmieszczeniu przemysłu motoryzacyjnego przeanalizowano także regionalne zróżnicowanie BIZ w tym sektorze w latach 1999-2015. W ostatniej części pracy przeanalizowano wzrost znaczenia eksportu wyrobów sektora motoryzacyjnego dla meksykańskiej gospodarki. Określono także rolę eksportu wyrobów tego sektora w eksporcie wyrobów przemysłowych z najbardziej zindustrializowanych stanów Meksyku. W badaniach regionalnych uwzględniono 16 spośród 32 stanów Meksyku, ze względu na fakt, iż w nich koncentrowało się ponad 90\% zatrudnienia i działalności przemysłowej związanej z tym sektorem. Dane do badań pochodziły w większości ze spisów gospodarczych (Censos Económicos..., 1999; 2009) oraz innych informacji gromadzonych przez meksykański Narodowy Instytut Statystyki i Geografii (Instituto Nacional de Estadística y Geografía - INEGI). Tak przeprowadzone postępowanie umożliwiło uzyskanie odpowiedzi na postawione pytania oraz pozwoliło zweryfikować postawioną hipotezę badawczą.

\section{HISTORIA ROZWOJU MEKSYKAŃSKIEGO PRZEMYSŁU MOTORYZACYJNEGO}

Od lat dwudziestych do początku lat sześćdziesiątych XX wieku powstawały i funkcjonowały w Meksyku fabryki montujące samochody w systemie częściowego bądź całościowego rozłożenia na elementy składowe (SKD - semi-knocked-down, CKD - completely-knocked-down). Wszystkie zakłady koncentrowały się w mieście Meksyk bądź jego najbliższym sąsiedztwie, co wynikało z faktu, iż był on też głównym rynkiem zbytu dla montowanych pojazdów. Na początku lat sześćdziesiątych XX wieku rząd meksykański, idąc wzorem innych państw Ameryki Łacińskiej, postanowił przyspieszyć proces industrializacji i rozwinąć narodowy przemysł samochodowy. Mając na uwadze liczne powiazania kooperacyjne tego przemysłu z innymi gałęziami oraz jego dużą innowacyjność, liczono, iż stanie się on kołem zamachowym rozwoju gospodarczego, podniesie poziom wiedzy technicznej i kwalifikacji siły roboczej oraz wzmocni i wspomoże ogólne tendencje modernizacyjne w gospodarce. 
Brak wystarczającego kapitału w kraju skłonił rząd do podjęcia inicjatywy zmuszającej międzynarodowe koncerny samochodowe do budowy fabryk produkcyjnych w Meksyku lub opuszczenia tego rynku. Przyjęty przez rząd w 1962 roku dekret dotyczący przemysłu motoryzacyjnego zakładał całkowity zakaz importu gotowych pojazdów. Udział krajowych podzespołów musiał osiągnąć $60 \%$ bezpośrednich kosztów produkcji pojazdu, zaś użycie zagranicznych surowców i podzespołów w produkcji wymagało zgody władz, przy czym każdy producent miał określony maksymalny limit produkcyjny. Firmy działające w sektorze części samochodowych nie mogły być własnością zagranicznych koncernów, ale musiały być co najmniej w 60\% oparte o kapitał lokalny, co miało ograniczyć wertykalną integrację i przyczynić się do powstania niezależnego meksykańskiego przemysłu części samochodowych.

Z początkowych siedmiu producentów samochodowych do początku lat osiemdziesiątych XX wieku ich liczba zmalała do pięciu (Ford, GM, Chrysler, Volkswagen, Nissan). Spadek ten wynikał głównie z faktu, iż firmy z meksykańskim kapitałem nie sprostały konkurencji i zakończyły produkcję lub zostały przejęte przez międzynarodowe koncerny (Bennett, Sharpe, 1984; 1985; Shapiro, 1993).

Prowadzona od 1962 roku polityka w sektorze motoryzacyjnym przyniosła znaczny sukces. Produkcja samochodów wzrosła z około 50 tys. sztuk w 1960 roku do 193 tys. w 1970 roku i aż 490 tys. w 1980 roku. Zakłady produkcyjne zlokalizowane były praktycznie w całości w mieście Meksyk oraz otaczających go stanach. Głównymi centrami produkcji były miasta Toluca i Cuautitlan w stanie Meksyk, Cuernavaca w stanie Morelos i Puebla w stolicy stanu o tej samej nazwie, w której swoje centrum produkcyjne zlokalizował koncern Volkswagen (Holmes, 1993).

Rozwijający się w warunkach realizowanej przez rząd strategii industrializacji, poprzez substytucję importu, przemysł motoryzacyjny cechował się jednak niską wydajnością produkcji, przestarzałymi technologiami, zbyt dużą liczbą produkowanych modeli, co uniemożliwiało osiągnięcie korzyści skali oraz praktycznie uniemożliwiało eksport, gdyż jego wyroby były niekonkurencyjne na zewnętrznych rynkach. Wobec pogarszającego się od drugiej polowy lat siedemdziesiątych XX wieku bilansu wymiany handlowej Meksyku rząd zdecydował się na stopniowe odchodzenie od wcześniej realizowanej polityki przemysłowej, starając się zachęcić koncerny samochodowe - a właściwie wymusić to na nich - do stopniowej modernizacji ich zakładów oraz wytwarzanych produktów, tak by sektor ten osiągnął konkurencyjność umożliwiającą eksport na rynki światowe, a zwłaszcza na chłonny rynek USA.

Zmiany te znalazły swoje odzwierciedlenie w rządowych dekretach dotyczących przemysłu motoryzacyjnego, ogłoszonych w 1977, 1983 i 1989 roku. Doprowadziły do stopniowego odejścia od wcześniej realizowanej strategii industrializacji poprzez substytucję importu na rzecz liberalizacji i deregulacji tego sektora gospodarki, zapewniając większą elastyczność działającym na meksykańskim rynku koncernom samochodowym i skłaniając je do osiągnięcia międzynarodowej konkurencyjności oraz zwiększenia zdolności eksportowych.

Zmiana państwowej polityki wobec sektora samochodowego zbiegła się z kryzysem zadłużeniowym, w jaki wpadł Meksyk na początku lat osiemdziesiątych XX wieku, i koniecznością zrównoważenia, a w dłuższej perspektywie utrzymania, dodatniego bilansu handlowego, aby zapewnić środki na obsługę zadłużenia zagranicznego. Zmusiło to władze do zmiany strategii w tym sektorze i skłonienia funkcjonujących na krajowym rynku międzynarodowych koncernów do rozwijania produkcji eksportowej, 
nawet kosztem lokalnego rynku, którego chłonność w połowie lat osiemdziesiątych kształtowała się na poziomie około 200 tys. sztuk rocznie. Ograniczenia chłonności wewnętrznego rynku na nowe samochody uświadomiły rządzącym konieczność zmiany polityki i umożliwienia koncernom produkcji eksportowej, co pozwoliłoby na dalszy rozwój tego sektora i zwiększenie jego znaczenia w krajowej gospodarce. Obserwując sukcesy, jakie odnosił sektor motoryzacyjny w nowo uprzemysławianych krajach Azji Wschodniej, takich jak Japonia czy Korea Płd., meksykańskie władze również zdecydowały się zmienić strategię rozwoju tego sektora na bardziej otwartą na eksport.

Zbiegło się to ze zmianą strategii głównych amerykańskich koncernów motoryzacyjnych, od przełomu lat siedemdziesiątych i osiemdziesiątych XX wieku wystawionych na coraz większą presję konkurencyjną ze strony japońskich producentów, którzy gwałtownie zwiększali swój udział w amerykańskim rynku motoryzacyjnym. Pod naciskiem rządu Stanów Zjednoczonych, coraz bardziej zaniepokojonego gwałtownie rosnącym ujemnym deficytem handlowym z Japonią, koncerny samochodowe z tego kraju zgodziły się dobrowolnie ograniczyć eksport samochodów do USA oraz przenieść część produkcji do tego kraju, co jeszcze bardziej wzmogło presję konkurencyjną na tzw. wielką trójkę z Detroit (GM, Ford, Chrysler). Starając się obniżyć koszty produkcji oraz poprawić swoją konkurencyjność, amerykańskie koncerny coraz bardziej zwiększały swoje inwestycje w Meksyku, do czego zachęcała także nowa polityka władz (Holmes, 1993; Taylor, 1993; Mortimore, 1995; Moreno-Brid, 1996).

Dekada lat osiemdziesiątych XX wieku okazała się przełomowa dla meksykańskiego przemysłu motoryzacyjnego. Złożyły się na to zmiany polityki państwa względem tego sektora oraz strategii rozwoju funkcjonujących na meksykańskim rynku koncernów samochodowych, co wywołało falę inwestycji bezpośrednich, z których większość zlokalizowano w nowych lokalizacjach położonych bliżej granicy z USA. Produkcja samochodów osobowych, która osiągnęła swoją największą liczbę 356 tys. sztuk w 1981 roku, zdołała ponownie osiągnąć ten poziom dopiero w 1989 roku, a następnie w ciągu kilku lat gwałtownie wzrosła do blisko 856 tys. w 1994 roku. Dokonało się to w dużej mierze dzięki poprawie jakości i konkurencyjności produkowanych w Meksyku pojazdów, co umożliwiło zwiększenie ich eksportu. 0 ile w połowie lat osiemdzisiątych XX wieku wynosił on zaledwie 50 tys. sztuk rocznie, to w 1989 roku osiągnął poziom około 150 tys. sztuk, zaś w 1994 roku wzrósł aż do 500 tys. sztuk (Mortimore 1995: 24).

Przeanalizowane powyżej procesy umożliwiły meksykańskiemu przemysłowi motoryzacyjnemu udaną transformację, pozwalającą na osiągnięcie międzynarodowej konkurencyjności produkcji i włączenie się w globalną wymianę handlową. $\mathrm{W}$ dniu wejścia w życie 1 stycznia 1994 roku porozumień tworzących NAFTA sektor ten był odpowiednio przygotowany i zmodernizowany, by konkurować swoimi wyrobami na tworzącym się wspólnym rynku. Dzięki nowym inwestycjom oraz modernizacji istniejących zakładów utrzymał swoją ważną pozycję w gospodarce, wytwarzając w 1993 roku 1,7\% PKB Meksyku. Jeszcze większą rolę odgrywał ten sektor w takich stanach, jak Morelos czy Coahuila, dostarczając odpowiednio: 7,4\% i 6,0\% ich PKB. W pierwszym przypadku miało to związek z modernizacją i rozbudową fabryki Nissana w Cuernavaca - stolicy stanu Morelos, leżącej około $85 \mathrm{~km}$ na południe od miasta Meksyk. Zaś w przypadku stanu Coahuila wiązało się to z nowymi inwestycjami GM w duże fabryki silników samochodowych i samochodów osobowych oraz Chryslera w fabrykę silników, zlokalizowanymi w mieście Ramos Arizpe w obszarze metropolitalnym Saltillo - stolicy stanu (tab. 1). 
Tab. 1. Zmiany znaczenia przemysłu samochodowego w głównych stanach Meksyku w tworzeniu PKB w latach 1985-1993

\begin{tabular}{|l|r|r|r|r|r|r|r|r|r|}
\hline \multirow{4}{*}{ Stan } & \multicolumn{3}{|c|}{$\begin{array}{c}\text { Udział stanu } \\
\text { w PKB przemysłu } \\
\text { samochodowego }\end{array}$} & \multicolumn{2}{c|}{$\begin{array}{c}\text { Udział PKB w przemyśle } \\
\text { motoryzacyjnym } \\
\text { w łącznym PKB }\end{array}$} & $\begin{array}{c}\text { Udział PKB w przemyśle } \\
\text { motoryzacyjnym } \\
\text { w PKB przemysłu } \\
\text { przetwórczego }\end{array}$ \\
\cline { 2 - 13 } & 1985 & 1988 & 1993 & 1985 & 1988 & 1993 & 1985 & 1988 & 1993 \\
\hline Aguascallentes & 1,24 & 0,84 & 1,52 & 3,13 & 1,87 & 2,99 & 11,32 & 6,35 & 15,13 \\
\hline Baja California & 1,21 & 1,22 & 0,19 & 0,88 & 0,78 & 0,14 & 5,13 & 4,07 & 0,94 \\
\hline Chihuahua & 3,82 & 6,72 & 4,95 & 2,23 & 3,36 & 2,92 & 12,18 & 15,27 & 17,80 \\
\hline Coahuila & 7,03 & 12,49 & 9,63 & 4,40 & 6,80 & 6,00 & 15,13 & 19,45 & 21,15 \\
\hline Distrito Federal & 23,18 & 19,81 & 23,44 & 1,90 & 1,51 & 1,68 & 6,89 & 5,11 & 7,81 \\
\hline Guanajuato & 1,48 & 1,43 & 1,20 & 0,80 & 0,71 & 0,60 & 3,60 & 2,70 & 3,51 \\
\hline Hidalgo & 4,97 & 3,18 & 3,68 & 5,56 & 3,04 & 4,01 & 17,77 & 10,37 & 16,14 \\
\hline Jalisco & 0,93 & 0,57 & 0,57 & 0,24 & 0,14 & 0,15 & 0,90 & 0,48 & 0,72 \\
\hline Mexico & 28,14 & 24,11 & 24,13 & 4,35 & 3,44 & 3,97 & 10,81 & 7,89 & 11,90 \\
\hline Morelos & 3,51 & 5,55 & 6,86 & 5,07 & 7,07 & 7,38 & 19,28 & 22,77 & 32,51 \\
\hline Nuevo Leon & 5,27 & 3,86 & 3,09 & 1,51 & 0,99 & 0,83 & 4,08 & 2,31 & 2,83 \\
\hline Puebla & 11,49 & 8,08 & 8,89 & 6,03 & 4,24 & 4,77 & 23,34 & 15,83 & 22,46 \\
\hline Queretaro & 3,65 & 2,48 & 1,91 & 5,00 & 3,07 & 2,34 & 12,66 & 6,68 & 7,98 \\
\hline San Luis Potosi & 1,63 & 1,10 & 0,86 & 1,68 & 0,97 & 0,84 & 6,00 & 3,13 & 3,74 \\
\hline Sonora & 0,20 & 5,31 & 6,48 & 0,13 & 3,14 & 4,25 & 1,00 & 18,58 & 26,43 \\
\hline Tamaulipas & 0,94 & 1,41 & 1,05 & 0,58 & 0,84 & 0,71 & 4,27 & 4,94 & 5,14 \\
\hline Meksyk ogółem & 98,71 & 98,17 & 98,46 & 1,71 & 1,63 & 1,73 & 7,34 & 6,03 & 8,59 \\
\hline
\end{tabular}

Źródło: opracowanie własne na podstawie La industria automotriz en Mexico (1994; 1998)

Na przełomie lat osiemdziesiątych i dziewięćdziesiątych XX wieku przemysł samochodowy w Meksyku uległ znacznej dekoncentracji, zaznaczając swoją obecność w 16 spośród 32 stanów, które łącznie dostarczały ponad 98\% PKB wytwarzanego w tym sektorze. Dzięki nowym inwestycjom zrealizowanym w latach 1979-1990 wzrosło znaczenie stanów leżących w północnej części kraju, takich jak: Sonora, Coahuila, Tamaulipas i Chihuahua. Ich udział w tworzeniu PKB przemysłu samochodowego wzrósł w latach 1985-1993 z 12,0\% do 22,1\%. Nadal jednak dominującą rolę odgrywały stany: Distrito Federal, Mexico i Puebla, choć ich udział w tworzeniu PKB sektora motoryzacyjnego w tym okresie zmniejszył się z 62,8\% do 56,5\% (tab. 1). Przedstawione powyżej historyczne zmiany w rozwoju i przestrzennej koncentracji sektora motoryzacyjnego wskazują, iż tendencje zarysowujące się na przełomie lat osiemdziesiątych i dziewięćdziesiątych XX wieku uległy wzmocnieniu w kolejnych dekadach, wraz dalszym jego rozwojem.

\section{NOWA FALA BIZ A ROZWÓJ MEKSYKAŃSKIEGO PRZEMYSŁU SAMOCHODOWEGO NA PRZEŁOMIE XX I XXI WIEKU}

Meksykański przemysł samochodowy zawdzięcza swoje powstanie inwestycjom bezpośrednim międzynarodowych koncernów samochodowych głównie z USA (GM, Ford, Chrysler), Europy Zachodniej (Volkswagen, Renault) oraz Japonii (Nissan) (Bennett, Sharpe, 1984; 1985; Shapiro, 1993). Zmiana polityki poprzemysłowej Meksyku, w obliczu wyczerpywania się modelu industrializacji opartej na substytucji importu, 
wywołała kolejną falę napływu BIZ do tego sektora, związaną z budową nowych, zaawansowanych technologicznie fabryk silników oraz samochodów przeznaczonych głównie na eksport (Carrillo, 1991; Mortimore, 1995; Moreno-Brid, 1996). Następna fala nowych inwestycji związana była z wejściem Meksyku do NAFTA oraz żywiołowym rozwojem produkcji eksportowej, głównie na rynek USA, która obejmowała zarówno gotowe pojazdy, jak i części oraz podzespoły - wykorzystując niższe koszty siły roboczej (Carrillo, 2000; 2004; Covarrubias, 2011; Wójtowicz, 2012; 2015).

W latach 1999-2015 w przemyśle samochodowym zainwestowano ponad 43,8 mld dol., co stanowiło 10\% ogólnego napływu BIZ do Meksyku. Zdecydowanie większy napływ odnotowano w sektorze części i podzespołów samochodowych, gdzie łączny napływ BIZ w tym okresie wyniósł blisko 27,3 mld, co stanowiło $62,2 \%$ ogólnej ich wartości (ryc. 1). Wynikało to - z jednej strony - z napływu nowych inwestycji globalnych korporacji specjalizujących się w produkcji części samochodowych, których obecność na tym rynku wymuszała kooperacja i konieczność bliskich kontaktów i współpracy z koncernami produkującymi gotowe pojazdy. $Z$ drugiej strony część inwestycji wiązała się z przejęciem lokalnych producentów części i podzespołów, którzy przestali być chronieni przez państwową politykę przemysłową i nie sprostali międzynarodowej konkurencji (Mortimore, 1995; Moreno-Brid 1996; Miranda 2007; Covarrubias 2011). Kolejnym czynnikiem skłaniającym do inwestycji w tym sektorze były niskie koszty siły roboczej, a szczególnie ułatwienia wprowadzane dla inwestorów produkujących w całości na eksport, związane z tzw. programem maquiladoras (Carrillo, 1997; Carrillo, Hualde, Quintero, 2005; Dorocki, Brzegowy, 2014).

Szczególny wzrost wielkości napływu BIZ odnotowano w latach 2012-2015, w tym okresie napłynęło aż 17,4 mld dol., co stanowiło blisko 40\% ogólnego napływu w latach

Ryc. 1. Zmiany wielkości i struktury BIZ w przemyśle samochodowym w latach 1999-2015

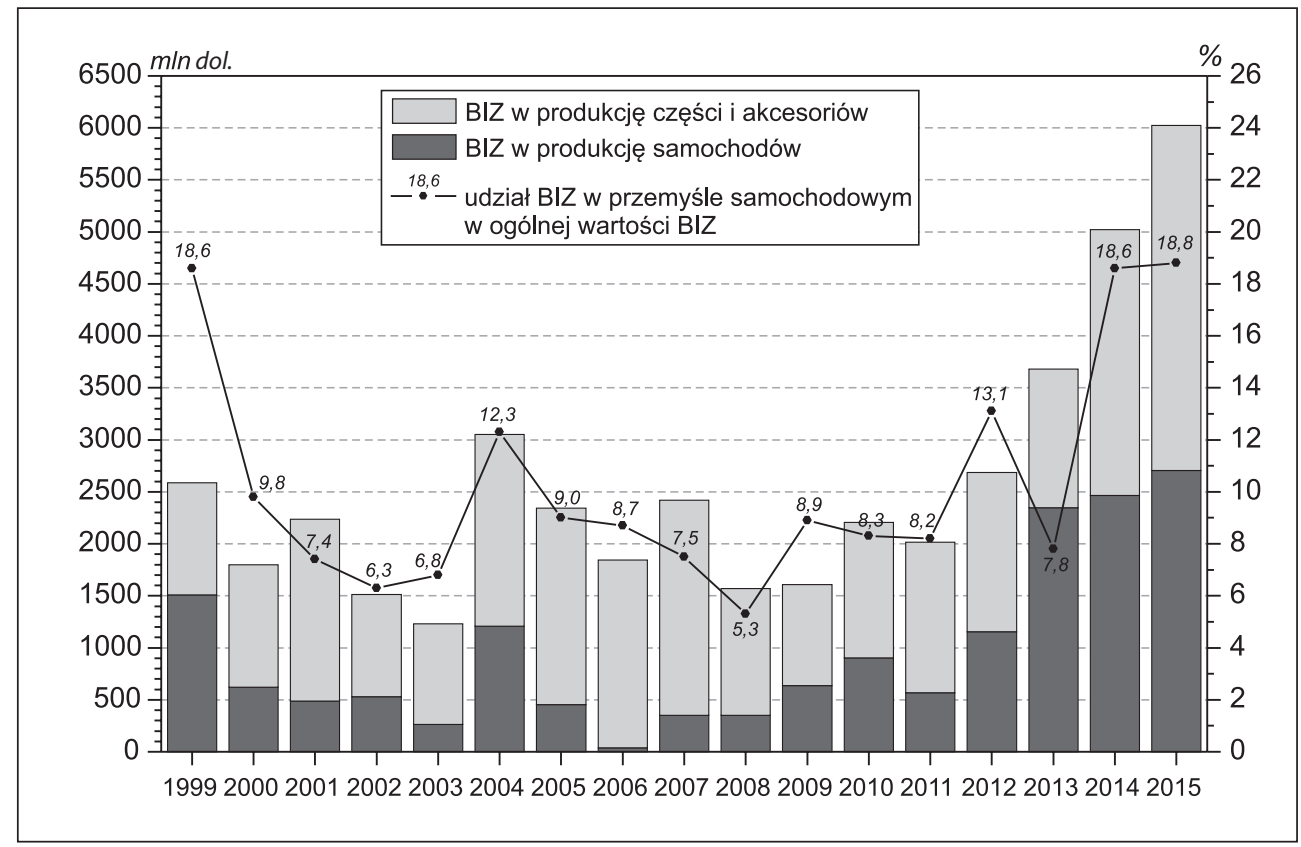

Źródło: opracowanie własne na podstawie Estadística oficial de los flujos de IED hacia México (2016) 
1999-2015. Okres ten charakteryzował się też szczególnie dużym napływem inwestycji związanych z produkcją samochodów, które osiągnęły 8,7 mld dol., czyli aż 52,3\% ogólnej ich wartości w latach 1999-2015 (ryc. 1). Nowe inwestycje przyczyniły się do znacznego wzrostu produkcji nowych pojazdów. W 2015 roku wyniosła ona 3,6 mln sztuk, co pozwoliło Meksykowi wyprzedzić Brazylię i stać się największym producentem samochodów w Ameryce Łacińskiej (The Mexican Automotive Industry..., 2016).

Wyraźnie zmieniła się również przestrzenna redystrybucja BIZ w Meksyku. Region centralny, obejmujący stany położone w sąsiedztwie Dystryktu Federalnego, będący do początku lat dziewięćdziesiątyh XX wieku głównym obszarem koncentracji przemysłu samochodowego, na początku XXI wieku wyraźnie stracił na znaczeniu (Wójtowicz, 2015). W latach 1999-2015 bezpośrednie inwestycje w sektorze motoryzacyjnym w regionie centralnym wyniosły blisko 11 mld dol., co stanowiło $25 \%$ ich ogólnego napływu do Meksyku.

Zdecydowanie większą rolę odegrał jednak region północny, który w tym okresie wchłonął blisko 21,7 mld dol., co stanowiło aż 49,4\% ich całkowitej wartości. Warto w tym miejscu wspomnieć, iż sam stan Chihuahua w tym okresie odnotował napływ w wielkości blisko 9,7 mld dol., czyli 22,1\% ogólnej wartości BIZ w przemyśle samochodowym.

Trzecim regionem o dużym znaczeniu w koncentracji działalności sektora motoryzacyjnego jest region Bajío, obejmujący stany z centralno-zachodniej części kraju, który w analizowanym okresie odnotował napływ blisko 11 mld dol. BIZ, co stanowiło $25 \%$ ogólnej ich wartości w sektorze motoryzacyjnym. W regionie Bajío główną rolę odgrywają stany Aguascalientes, Guanajuato, San Luis Potosi i Queretaro, które wchłonęły łącznie blisko 10 mld dol., czyli 91\% napływu BIZ do tego regionu (ryc. 2).

Ryc. 2. Skumulowany napływ BIZ do stanów Meksyku w latach 1999-2015

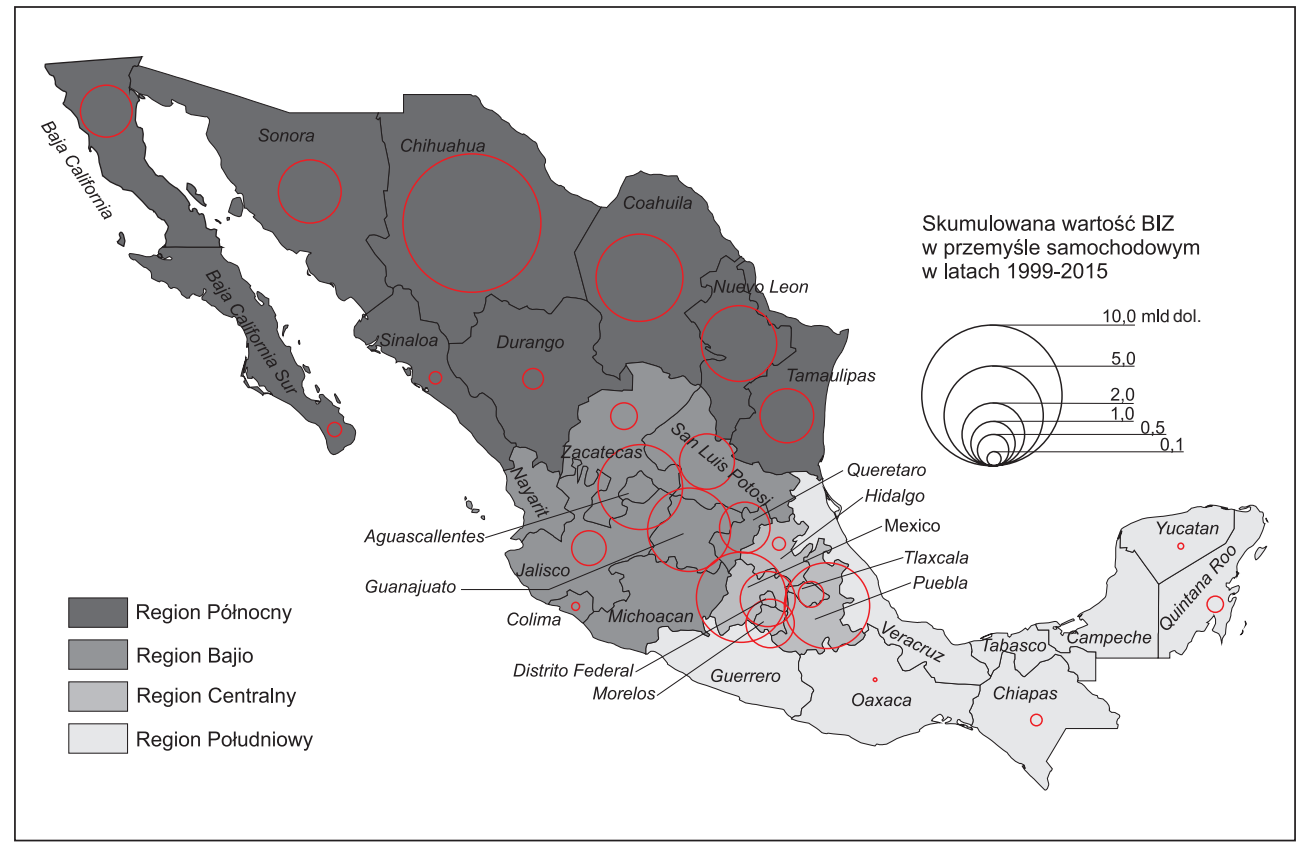

Źródło: opracowanie własne na podstawie danych Estadística oficial de los flujos de IED hacia México (2016) 
W wyniku scharakteryzowanej powyżej ostatniej fali BIZ w meksykańskim sektorze motoryzacyjnym doszło do znacznych regionalnych przesunięć jego działalności. W produkcji przemysłu samochodowego wyraźnie wzrosło znaczenie stanów graniczących z USA. Zwiększyła się także rola wspomnianych powyżej czterech stanów z regionu Bajio, w których powstały nowoczesne zakłady, również głównie nastawione na eksport. Natomiast BIZ w regionie centralnym, będącym kolebką meksykańskiego sektora motoryzacyjnego, pozwoliły zmodernizować istniejące zakłady oraz choć częściowo zachować pozycję, jaką stany te odgrywały w krajowym przemyśle samochodowym. Największy napływ BIZ odnotowały w tym regionie stany Puebla i Meksyk (ryc. 2). W pierwszym przepadku głównym inwestorem był koncern Volkswagen, który zmodernizował i rozbudował swoje zakłady mieście Puebla. W stanie Meksyk główny strumień BIZ związany były z modernizacją i przebudową zakładów koncernów GM i Chrysler - Fiat w mieście Toluca (Juáres, 2005; Carbajal Suárez, 2012; Wójtowicz, 2015).

\section{WSPÓŁCZESNY ROZWÓJ MEKSYKAŃSKIEGO PRZEMYSŁU SAMOCHODOWEGO I WZROST JEGO ZNACZENIA W GOSPODARCE KRAJU}

W latach osiemdziesiątych XX wieku zaszły znaczące zmiany polityki przemysłowej względem sektora motoryzacyjnego, zmieniły się też strategie głównych koncernów motoryzacyjnych, co było wywołane globalnymi i regionalnymi uwarunkowaniami. Wskazane powyżej trzy główne grupy czynników odgrywały najważniejszą rolę w dalszym rozwoju tego sektora w Meksyku. Obserwowany współcześnie sukces zależał w dużej mierze od zmiany paradygmatu rozwoju z opartego na rynku wewnętrznym w oparty w większym stopniu na produkcji eksportowej. Zmiana ta mogła się okazać nieskuteczna, gdyby nie pokryła się z nowymi strategiami rozwojowymi głównych koncernów motoryzacyjnych działających na meksykańskim rynku (szczególnie: GM, Ford i Chrysler), które w obliczu nasilającej się konkurencji japońskich koncernów zdecydowały się w większym stopniu zainwestować w rozwój produkcji w Meksyku, wykorzystując niższe koszty produkcji. Kolejnym czynnikiem zwiększającym napływ inwestycji motoryzacyjnych do tego kraju była postępująca regionalna integracja gospodarcza, której zwieńczeniem było powstanie w 1994 roku NAFTA. Splot tych czynników przyczynił się do znacznego wzrostu znaczenia przemysłu samochodowego, zarówno pod względem wielkości produkcji gotowych pojazdów, jak i wielkości zatrudnienia oraz udziału w wytwarzaniu wartości dodanej brutto (WDB).

W latach 1985-2014 zatrudnienie w tym sektorze gospodarki wzrosło ponad czterokrotnie, ze 145,9 tys. do blisko 588,2 tys. zatrudnionych. Wzrosło też znaczenie sektora w ogólnym zatrudnieniu w przemyśle przetwórczym z 7,0\% do 11,6\%. W badanym okresie zaszły też znaczące zmiany w rozmieszczeniu zatrudnienia, chociaż cały czas przemysł samochodowy koncentrował się głównie w 16 stanach, które w 1985 roku skupiały aż 98,1\% ogółu zatrudnienia, a do 2014 roku ich udział zmniejszył się do $91,9 \%$. Wskazuje to na stosunkowo niewielkie przesunięcia zatrudnienia poza ukształtowaną do połowy lat osiemdziesiątych XX wieku strukturę przestrzenną przemysłu motoryzacyjnego w Meksyku. Niemniej jednak w obrębie 16 stanów, na których terenie występowały zakłady przemysłowe związane z tym sektorem, doszło do znaczących przesunięć (tab. 2 i 3).

W 1985 roku zatrudnienie w przemyśle samochodowym koncentrowało się w trzech stanach regionu centralnego (Dystrykcie Federalnym, Mexico i Puebla), które 
łącznie skupiały 58,9\% ogółu zatrudnionych, a udział całego regionu był jeszcze wyższy i wynosił aż 66,3\%. W tym samym czasie stany zaliczane do regionu Bajío koncentrowały jedynie 11,9\%, a stany z regionu północnego 19,7\% ogółu zatrudnionych w przemyśle samochodowym. W wyniku realizacji przez międzynarodowe koncerny samochodowe strategii rozwoju produkcji eksportowej na rynek Stanów Zjednoczonych, skutkującej nowymi inwestycjami na obszarach leżących na północ od stolicy, znacznie spadło znaczenie regionu centralnego. W 2014 roku koncentrował on jedynie 16\% ogółu zatrudnionych, a udział trzech dominujących wcześniej stanów zmniejszył się do 12,2\%. W tym samym roku udział regionu Bajío wynosił 19,1\%, a regionu północnego aż 59,2\% ogółu zatrudnionych w sektorze motoryzacyjnym (tab. 2).

Tab. 2. Udział głównych stanów w ogólnym zatrudnieniu w przemyśle samochodowym Meksyku w latach 1985-2014

\begin{tabular}{|l|r|r|r|r|r|r|r|}
\hline \multicolumn{1}{|c|}{ Stan } & 1985 & 1988 & 1993 & 1999 & 2004 & 2009 & 2014 \\
\hline Aguascallentes & 1,7 & 1,8 & 3,5 & 3,5 & 2,0 & 2,9 & 3,8 \\
\hline Baja California & 1,1 & 3,0 & 3,0 & 3,8 & 3,0 & 2,2 & 3,7 \\
\hline Chihuahua & 1,0 & 2,7 & 4,2 & 5,7 & 30,2 & 20,0 & 18,6 \\
\hline Coahuila & 8,4 & 6,4 & 7,2 & 7,8 & 13,4 & 10,9 & 14,7 \\
\hline Distrito Federal & 18,9 & 15,5 & 13,6 & 8,1 & 2,8 & 2,6 & 2,4 \\
\hline Guanajuato & 2,7 & 3,3 & 3,5 & 7,1 & 3,8 & 4,7 & 5,5 \\
\hline Hidalgo & 4,6 & 4,9 & 3,0 & 1,3 & 0,2 & 0,3 & 0,1 \\
\hline Jalisco & 2,5 & 4,9 & 5,2 & 6,6 & 2,9 & 2,8 & 2,5 \\
\hline Mexico & 29,0 & 23,7 & 23,4 & 20,4 & 8,3 & 9,2 & 5,2 \\
\hline Morelos & 2,8 & 2,6 & 3,2 & 1,7 & 0,9 & 1,0 & 1,2 \\
\hline Nuevo Leon & 6,0 & 6,3 & 5,7 & 7,3 & 7,6 & 8,0 & 7,5 \\
\hline Puebla & 11,0 & 7,2 & 8,8 & 10,6 & 4,8 & 6,7 & 4,6 \\
\hline Queretaro & 3,9 & 3,4 & 3,0 & 3,7 & 3,0 & 4,5 & 3,8 \\
\hline San Luis Potosi & 1,1 & 2,2 & 2,2 & 2,5 & 2,6 & 4,3 & 3,5 \\
\hline Sonora & 0,8 & 2,8 & 1,7 & 1,6 & 3,5 & 6,1 & 5,5 \\
\hline Tamaulipas & 2,4 & 5,4 & 5,8 & 5,9 & 8,4 & 8,4 & 9,2 \\
\hline Łącznie & 98,1 & 96,0 & 96,8 & 97,5 & 97,4 & 94,7 & 91,9 \\
\hline Ogółem (tys. osób) & 145,9 & 186,9 & 214,6 & 230,7 & 535,2 & 552,2 & 588,2 \\
\hline
\end{tabular}

Źródło: opracowanie własne na podstawie Censos Económicos... (1999; 2009; 2014)

Wzrost udziału regionu północnego w ogólnym zatrudnieniu w przemyśle samochodowym nastąpił głównie dzięki napływowi nowych inwestycji i rozbudowie istniejących zakładów. W latach 1985-2014 liczba zatrudnionych zwiększyła się z 29,1 tys. do 371,3 tys. osób. Warto podkreślić, iż w samym stanie Chihuahua zatrudnienie wzrosło z 1,4 tys. do 109,6 tys. osób, a w Coahuila z 12,3 tys. do blisko 86,5 tys. osób. Podobne przyrosty zatrudnienia, choć na mniejszą skalę, odnotowano także w głównych stanach regionu Bajío, takich jak Aguascalientes (z 2,5 tys. do 22,3 tys. osób), Guanajuato (4,0 tys. do 32,4 tys. osób), Queretaro (5,7 tys. do 22,5 tys. osób), San Luis Potosi (1,6 tys. do 20,3 tys. osób).

Natomiast utrata znaczenia przez stany regionu centralnego w rozmieszczeniu zatrudnienia w sektorze motoryzacyjnym wiązała się najczęściej ze znaczącym spadkiem liczby zatrudnionych. Taka sytuacja miała miejsce w Dystrykcie Federalnym, w którym zatrudnienie w przemyśle samochodowym spadło z 27,6 tys. do 14,3 tys. osób, oraz 
w stanie Meksyk, gdzie zmniejszyło się ono z 42,4 tys. do 30,3 tys. osób. Wiązało się to z głęboką restrukturyzacją i modernizacją zakładów przemysłu samochodowego w tych stanach, zwiększającą mechanizację produkcji i przenoszącą część działalności do nowych miejsc.

Odmienną sytuację zaobserwowano natomiast w stanie Puebla, który również odnotował spadek udziału w ogólnym zatrudnieniu w sektorze motoryzacyjnym z 11,0\% do 4,6\%, choć w liczbach bezwzględnych wzrosło ono z 16,0 tys. do 27,3 tys. osób (tab. 2). Wiązało się to $\mathrm{z}$ odmienną strategią koncernu Volkswagen, który modernizował i rozbudowywał zakłady zlokalizowane w tym stanie, podczas gdy działające w stanach Meksyk i Dystrykt Federalny koncerny GM, Ford, Chrysler i Nissan dużą część nowych inwestycji zlokalizowały w stanach leżących bliżej granicy z USA (Mortimore, 1995; Miranda, 2007; Covarrubias, 2011; Wójtowicz, Rachwał, 2014).

Tab. 3. Udział zatrudnienia w przemyśle samochodowym w ogólnym zatrudnieniu w przemyśle przetwórczym głównych stanów Meksyku w latach 1988-2014

\begin{tabular}{|l|r|r|r|r|r|r|}
\hline \multicolumn{1}{|c|}{ Stan } & 1988 & 1993 & 1999 & 2004 & 2009 & 2014 \\
\hline Aguascallentes & 9,6 & 15,7 & 11,7 & 15,7 & 21,9 & 25,5 \\
\hline Baja California & 7,2 & 4,5 & 3,6 & 6,4 & 4,4 & 6,8 \\
\hline Chihuahua & 3,1 & 4,0 & 3,7 & 45,8 & 31,9 & 29,3 \\
\hline Coahuila & 10,9 & 12,2 & 9,5 & 33,5 & 29,9 & 29,6 \\
\hline Distrito Federal & 5,9 & 5,8 & 3,9 & 3,4 & 3,6 & 4,0 \\
\hline Guanajuato & 5,2 & 4,5 & 7,1 & 9,0 & 9,5 & 9,4 \\
\hline Hidalgo & 20,1 & 10,8 & 4,0 & 1,9 & 2,2 & 0,9 \\
\hline Jalisco & 5,2 & 4,9 & 4,7 & 4,7 & 4,0 & 3,7 \\
\hline Mexico & 11,6 & 11,4 & 9,7 & 9,8 & 9,6 & 5,7 \\
\hline Morelos & 16,9 & 16,8 & 9,7 & 11,0 & 10,4 & 12,8 \\
\hline Nuevo Leon & 5,7 & 4,8 & 5,2 & 12,6 & 12,3 & 10,5 \\
\hline Puebla & 11,6 & 11,3 & 10,9 & 12,2 & 15,7 & 11,4 \\
\hline Queretaro & 12,2 & 10,2 & 9,4 & 17,2 & 20,9 & 13,7 \\
\hline San Luis Potosi & 7,8 & 6,3 & 7,7 & 15,8 & 22,2 & 16,3 \\
\hline Sonora & 8,2 & 4,1 & 2,8 & 14,8 & 21,0 & 18,3 \\
\hline Tamaulipas & 10,3 & 9,5 & 7,2 & 21,1 & 19,9 & 23,1 \\
\hline Meksyk ogółem & 7,0 & 6,4 & 5,5 & 12,7 & 11,8 & 11,6 \\
\hline
\end{tabular}

Źródło: opracowanie własne na podstawie Censos Económicos... (1999; 2009; 2014)

Wraz z przenoszeniem działalności produkcyjnej w sektorze motoryzacyjnym do stanów północnych ich struktura zatrudnienia stawała się coraz bardziej zdominowana przez ten sektor. Jest to szczególnie wyraźnie widoczne w takich stanach, jak: Coahuila, Chihuahua czy Tamaulipas, w których przemysł samochodowy koncentrował w 2014 roku odpowiednio: 29,6\%, 29,3\% i 23,1\% ogółu zatrudnienia w przemyśle przetwórczym. Natomiast w przypadku stanów z regionu centralnego, tracących na znaczeniu w ogólnej koncentracji przemysłu samochodowego, zmalało także jego znaczenie w lokalnej strukturze zatrudnienia w przemyśle przetwórczym. Najbardziej drastycznym przypadkiem był stan Hidalgo, w którym udział zatrudnienia w przemyśle samochodowym spadł z 20,1\% do 0,9\% ogółu zatrudnionych w przemyśle przetwórczym. Podobny spadek, choć na mniejszą skalę, odnotowano w przypadku stanów Meksyk oraz Morelos (tab. 3). 
Podobne przemiany jak w przypadku zmian wielkości i rozmieszczenia zatrudnienia zaobserwowano również, analizując udział poszczególnych regionów i stanów w wartości dodanej brutto przemysłu samochodowego. Co prawda w przeciwieństwie do zarysowującej się niewielkiej dekoncentracji zatrudnienia poza analizowane 16 stanów, w przypadku WDB ich udział zarówno na początku, jak i na końcu badanego okresu utrzymuje się na podobnym poziomie około 98\%, niemniej jednak w ich obrębie dokonały się zasadnicze przesunięcia udziałów. W 1985 roku stany regionu centralnego wytwarzały 60,3\% ogółu WDB w przemyśle samochodowym, jednak do 2014 roku ich udział zmniejszył się do 28,9\%. Szczególnie drastyczny spadek udziału w tworzeniu WDB odnotowano w przypadku Dystryktu Federalnego i stanu Hidalgo, które do 2014 roku praktycznie zupełnie straciły na znaczeniu (tab. 4).

Tab. 4. Udział głównych stanów w wartości dodanej brutto (WDB) przemysłu samochodowego w Meksyku w latach 1985-2014

\begin{tabular}{|l|r|r|r|r|r|r|r|}
\hline \multicolumn{1}{|c|}{ Stan } & 1985 & 1988 & 1993 & 1999 & 2004 & 2009 & 2014 \\
\hline Aguascallentes & 1,8 & 0,9 & 4,3 & 5,5 & 4,1 & 7,5 & 4,1 \\
\hline Baja California & 1,2 & 0,7 & 1,5 & 1,9 & 1,6 & 2,5 & 3,3 \\
\hline Chihuahua & 1,2 & 4,5 & 1,2 & 2,8 & 18,7 & 10,4 & 8,2 \\
\hline Coahuila & 16,1 & 24,2 & 8,1 & 11,4 & 10,9 & 15,7 & 15,1 \\
\hline Distrito Federal & 11,9 & 9,4 & 17,4 & $-4,1$ & $-0,1$ & 1,0 & 0,1 \\
\hline Guanajuato & 2,2 & 2,5 & 1,4 & 19,9 & 12,6 & 6,5 & 6,2 \\
\hline Hidalgo & 5,0 & 2,4 & 2,8 & 0,3 & 0,2 & 0,2 & 0,1 \\
\hline Jalisco & 1,6 & 2,4 & 6,1 & 3,8 & 1,6 & 2,2 & 1,9 \\
\hline Mexico & 18,2 & 19,7 & 25,0 & 20,2 & 10,1 & 10,8 & 9,8 \\
\hline Morelos & 6,3 & 16,1 & 11,4 & 3,4 & 1,9 & 1,9 & 2,5 \\
\hline Nuevo Leon & 4,1 & 2,9 & 3,8 & 5,8 & 7,3 & 7,5 & 10,1 \\
\hline Puebla & 18,9 & 6,1 & 5,0 & 11,6 & 17,1 & 14,0 & 16,4 \\
\hline Queretaro & 5,9 & 2,9 & 2,8 & 4,9 & 4,3 & 4,6 & 2,3 \\
\hline San Luis Potosi & 2,5 & 1,3 & 1,4 & 1,8 & 2,4 & 2,8 & 3,7 \\
\hline Sonora & 0,3 & 1,2 & 3,6 & 7,5 & 2,1 & 6,4 & 11,7 \\
\hline Tamaulipas & 1,1 & 1,8 & 2,4 & 2,2 & 4,2 & 4,2 & 2,3 \\
\hline Łącznie & 98,1 & 99,2 & 98,0 & 98,9 & 99,0 & 98,3 & 97,8 \\
\hline
\end{tabular}

Źródło: opracowanie własne na podstawie Censos Económicos... (1999; 2009; 2014)

Odmienną sytuację odnotowano w przypadku regionu północnego, którego udział w tworzeniu WDB w sektorze motoryzacyjnym wzrósł z 24\% w 1985 roku do blisko 51\% w 2014 roku. W przypadku tego regionu na szczególną uwagę zasługują stany Sonora i Chihuahua, które w analizowanym okresie zwiększyły udziały w tworzeniu WDB odpowiednio z 0,3\% do 11,7\% i z 1,2\% do 8,2\% (tab. 4). Udało się to osiągnąć głównie dzięki rozbudowie kompleksów produkcyjnych Forda w Hermosillo w stanie Sonora i mieście Chihuahua, będącym stolicą stanu o tej samej nazwie (Carrillo, 2004; Wójtowicz, Rachwał, 2014).

W badanym okresie zyskuje na znaczeniu w tworzeniu WDB przemysłu samochodowego także region Bajío, którego udział zwiększył się z 14\% do 18,2\% (tab. 4). W tym regionie na szczególną uwagę zasługują stany Aguascalientes, z rozbudowanym niedawno kompleksem produkcyjnym dwóch fabryk Nissana, oraz Guanajuato z zakładami Mazdy, GM, Volkswagena i Hondy. W stanie Aguascalientes budowę nowych 
fabryk samochodów osobowych rozpoczęły także koncerny Mercedes-Benz i Infiniti (Wójtowicz, Rachwał, 2014; The Mexican Automotive Industry..., 2016).

Nowe inwestycje związane z rozbudową zakładów sektora motoryzacyjnego doprowadziły w przypadku niektórych stanów do jego wyraźnej obecności w strukturze WDB. Na szczególną uwagę zasługują stany Puebla i Aguascalientes, gdzie sektor ten dostarczał w 2014 roku odpowiednio 34,8\% i 30,4\% łącznej WDB. Bardzo wyraźnie obecność tego sektora zaznaczała się także w tworzeniu WDB stanów Chihuahua, Sonora i Coahuila, w których wynosiła w 2014 roku odpowiednio: 21,5\%, 23,3\% i 26,5\% WDB. Wzrósł także udział przemysłu samochodowego w tworzeniu WDB w skali całego kraju, z blisko 4,6\% w 1999 roku do 6,1\% w 2014 roku. Świadczy to o rosnącym znaczeniu tego sektora nie tylko dla wybranych stanów, ale także w skali ogólnokrajowej (tab. 5).

Tab. 5. Udział przemysłu samochodowego w łącznej wartości dodanej brutto (WDB) głównych stanów Meksyku w latach 1999-2014

\begin{tabular}{|l|r|r|r|r|}
\hline \multicolumn{1}{|c|}{ Stany } & 1999 & 2004 & 2009 & 2014 \\
\hline Aguascallentes & 26,65 & 20,89 & 35,66 & 30,41 \\
\hline Baja California & 2,62 & 2,87 & 4,22 & 9,18 \\
\hline Chihuahua & 3,72 & 25,52 & 16,01 & 21,54 \\
\hline Coahuila & 14,56 & 18,95 & 22,63 & 0,02 \\
\hline Distrito Federal & $-0,71$ & $-0,01$ & 0,17 & 10,90 \\
\hline Guanajuato & 26,19 & 18,87 & 8,93 & 0,72 \\
\hline Hidalgo & 2,06 & 0,83 & 1,39 & 2,44 \\
\hline Jalisco & 2,75 & 1,45 & 1,83 & 9,04 \\
\hline Mexico & 9,11 & 6,51 & 6,75 & 18,56 \\
\hline Morelos & 17,13 & 8,79 & 10,71 & 7,53 \\
\hline Nuevo Leon & 3,66 & 4,72 & 4,63 & 34,85 \\
\hline Puebla & 19,61 & 27,73 & 23,39 & 7,99 \\
\hline Queretaro & 12,28 & 13,87 & 11,51 & 13,90 \\
\hline San Luis Potosi & 5,38 & 8,88 & 8,42 & 23,31 \\
\hline Sonora & 13,42 & 5,44 & 11,20 & 5,14 \\
\hline Tamaulipas & 3,53 & 6,42 & 5,72 & 6,08 \\
\hline Meksyk ogółem & 4,56 & 4,78 & 4,19 & \\
\hline
\end{tabular}

Źródło: opracowanie własne na podstawie Censos Económicos... (1999; 2009; 2014)

Podsumowując tą część analizy, warto jeszcze raz podkreślić, iż wraz z rozwojem przemysłu samochodowego, mierzonym wzrostem zatrudnienia oraz wartości dodanej brutto (WDB), doszło do jego wyraźnego przesunięcia z centrum Meksyku w kierunku północnym do stanów leżących bliżej granicy z USA. To stany leżące w regionie północnym i Bajío odnotowały najwyższy przyrost zatrudnienia, a także najbardziej zwiększyły udział w tworzeniu WDB sektora motoryzacyjnego. W przypadku kilku z nich przemysł samochodowy stał się dominującym sektorem przemysłu, co w dłuższej perspektywie może być niekorzystne i silnie uzależniać ich gospodarki poprzez swój udział w uzyskiwanych wpływach podatkowych i strukturze zatrudnienia. Niemniej jednak obecnie można zauważyć, że stany z dobrze rozwiniętym przemysłem samochodowym charakteryzują się wyższym poziomem rozwoju społeczno-gospodarczego, a nowe inwestycje motoryzacyjne w regionie Bajío i północnym pozwoliły tym 
regionom nadrobić część zaległości w stosunku do najlepiej rozwiniętych centralnych obszarów Meksyku.

Natomiast brak większych zakładów sektora motoryzacyjnego w stanach regionu południowego może być, przynajmniej w przypadku niektórych z nich, przyczyną ich niskiego poziomu rozwoju społeczno-gospodarczego. Rozwój przestrzenny przemysłu samochodowego w ostatnich dekadach może się zatem przyczyniać do pogłębiania podziału Meksyku na dwa zasadnicze regiony: słabiej rozwinięte południe kraju oraz lepiej rozwiniętą część centralną i północną (Moreno-Brid, Ros, 2009).

\section{ROZWÓJ MEKSYKAŃSKIEGO PRZEMYSŁU SAMOCHODOWEGO A WZROST EKSPORTU JEGO WYROBÓW}

Zmiana polityki względem sektora motoryzacyjnego, zapoczątkowana na przełomie lat siedemdziesiątych i osiemdziesiątych XX wieku, otwierająca go na większy napływ importowanych części i gotowych pojazdów, doprowadziła do gwałtownego wzrostu deficytu handlowego w wymianie międzynarodowej, który w 1982 roku wyniósł ponad 2,1 mld dol. i był jednym z czynników pogłębiających kryzys gospodarczy w kraju (Unger, 1991: 114). Zdopingowało to również meksykański rząd do wzmocnienia polityki proeksportowej w tym sektorze, zmuszającej działające na krajowym rynku koncerny samochodowe do osiągnięcia dodatniego bilansu handlowego.

Modernizacja meksykańskiego sektora motoryzacyjnego i wprowadzanie do produkcji nowych modeli wymagały jednak znaczącego wzrostu importu części i podzespołów samochodowych, których wytwarzaniu nie mogli sprostać miejscowi producenci. Prowadziło to do sytuacji, w której jeszcze na początku lat dziewięćdziesiątych Meksyk notował ujemny bilans wymiany handlowej wyrobami przemysłu motoryzacyjnego. Główną jego składową był bardzo wysoki import części, wynoszący w 1993 roku ponad 8,7 mld dol., podczas gdy łączna wartość eksportu wyrobów tego sektora z Meksyku wyniosła zaledwie 6,1 mld dol. (Mortimore, 1995: 29; Moreno-Brid, 1996). Od 1994 roku sytuacja uległa zmianie, co wiązało się z wejściem w życie porozumień powołujących NAFTA i gwałtownym wzrostem eksportu wyrobów przemysłu samochodowego, głównie do USA. Wzrost ten nie byłby możliwy, gdyby nie wcześniejsze inwestycje modernizujące meksykańskie zakłady i dostosowujące ich produkcję do międzynarodowych standardów. Transformacja istniejących zakładów oraz budowa nowych fabryk, nastawionych już w całości na eksport, podniosły konkurencyjność wytwarzanych w Meksyku samochodów, silników oraz innych podzespołów i otworzyły przed nimi wymagające rynki państw wysoko rozwiniętych, a w szczególności chłonny rynek USA (Mortimore, 1995; Moreno-Brid, 1996; Carrillo, 2000).

Od 1995 roku wartość eksportu meksykańskiego sektora motoryzacyjnego żywiołowo wzrastała z poziomu 12,2 mld dol. do 42,6 mld dol. w 2008 roku. Wzrost eksportu w tym sektorze wykazywał podobną dynamikę wzrostu jak eksport ogółem, stąd też jego udział w ogólnej wartości eksportu w tym okresie pozostał bez większych zmian, oscylując wokół 15\% (ryc. 3).

Sytuacja zmieniła się gwałtownie w 2009 roku w wyniku kryzysu gospodarczego na rynku USA, który szczególnie dotknął amerykańskie koncerny motoryzacyjne, silnie zaangażowane w działalność produkcyjną w Meksyku, której większość trafiała potem na amerykański rynek (Wójtowicz, 2011). Wielkość eksportu spadła w tym roku do poziomu 33,6 mld dol., czyli o ponad 21,1\%, prowadząc do bardzo głębokiego kryzysu 
Ryc. 3. Udział wyrobów przemysłu motoryzacyjnego w międzynarodowej wymianie towarowej Meksyku w latach 1995-2015

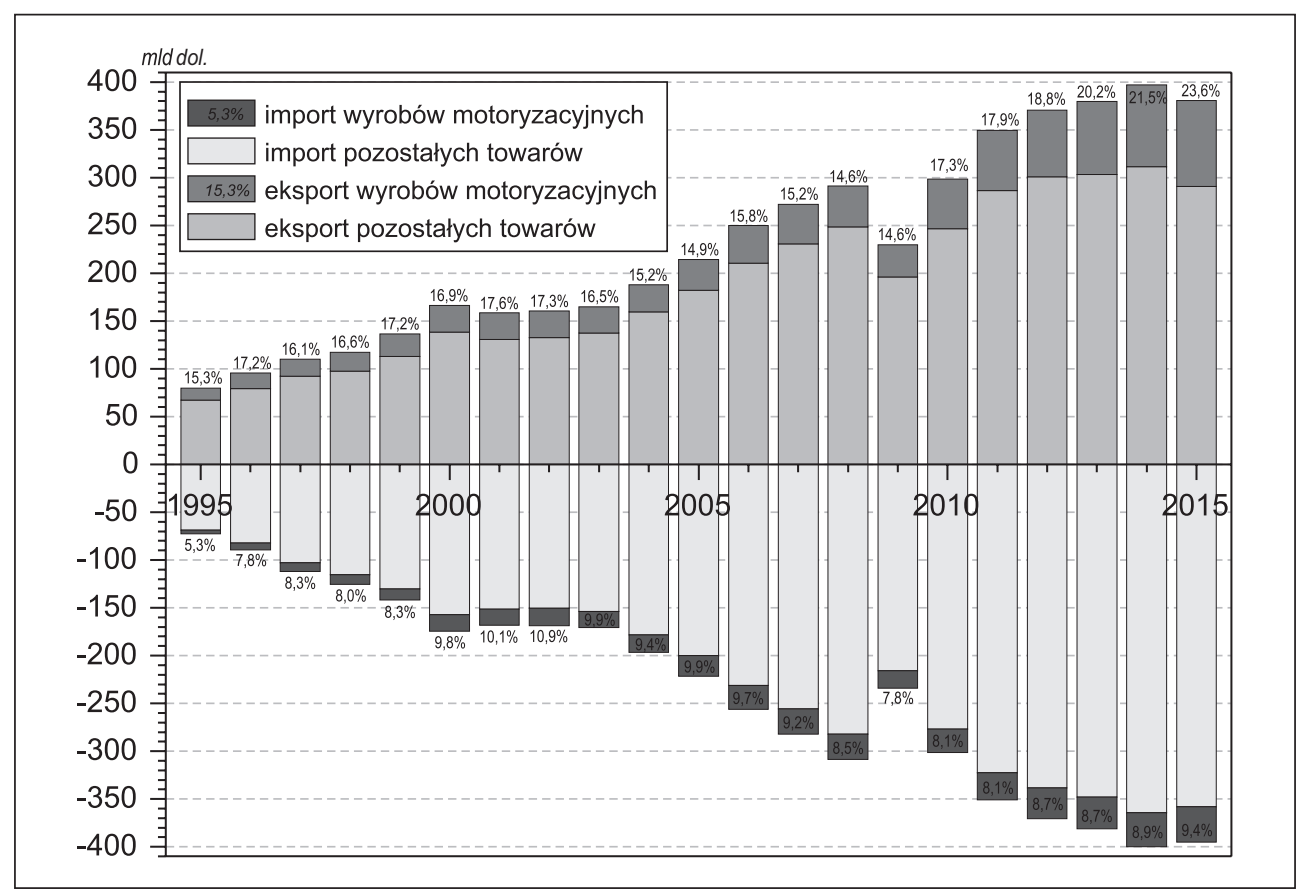

Źródło: opracowanie własne na bazie danych UNCTAD (2016)

w meksykańskim przemyśle samochodowym, który na szczęście okazał się krótkotrwały, gdyż już w kolejnym roku wielkość eksportu osiągnęła 51,5 mld dol. i była o 20,1\% większa niż w roku przed kryzysem. Od 2010 roku obserwujemy także dalszy dynamiczny wzrost eksportu wyrobów tego sektora, który w 2015 roku osiągnął wartość blisko 90 mld dol., co stanowiło aż 23,6\% ogólnej wartości meksykańskiego eksportu. Sektor motoryzacyjny stał się zatem w ostatnich latach jednym z głównych kół napędowych meksykańskiego eksportu, zwiększającym wpływy dewizowe i poprawiającym ciągle ujemny bilans handlu zagranicznego (rys. 3).

Meksykański przemysł samochodowy od początku funkcjonowania NAFTA cechuje się dodatnim bilansem wymiany handlowej. W latach 1995-2005 oscylował on pomiędzy 8 a 10 mld dol., by następnie w latach 2006-2009 wahać się pomiędzy 14 a 16 mld dol. Natomiast od 2010 roku wykazuje gwałtowny wzrost, sięgając blisko 53 mld dol. w 2015 roku (ryc. 4). Tak gwałtowny wzrost eksportu meksykańskiego przemysłu samochodowego oraz poprawa bilansu handlowego nie byłyby możliwe bez wspomnianego wcześniej dużego napływu BIZ, zwiększających produkcję zarówno nowych pojazdów, jak i części oraz podzespołów. Szczególnie rozwój sektora produkującego części samochodowe był bardzo istotny i przyczynił się do znacznego spowolnienia ich importu z zagranicy. Był on też poniekąd wymuszony przez strategie produkcyjne głównych koncernów samochodowych, wymagających od swoich głównych poddostawców bliskości geograficznej i dostaw just-in-time, typowych dla wprowadzanego przez większość koncernów szczupłego systemu produkcji (lean production) (Wójtowicz, 2015). 
Ryc. 4. Zmiany wielkości międzynarodowej wymiany handlowej Meksyku wyrobami przemysłu motoryzacyjnego ogółem w latach 1995-2015

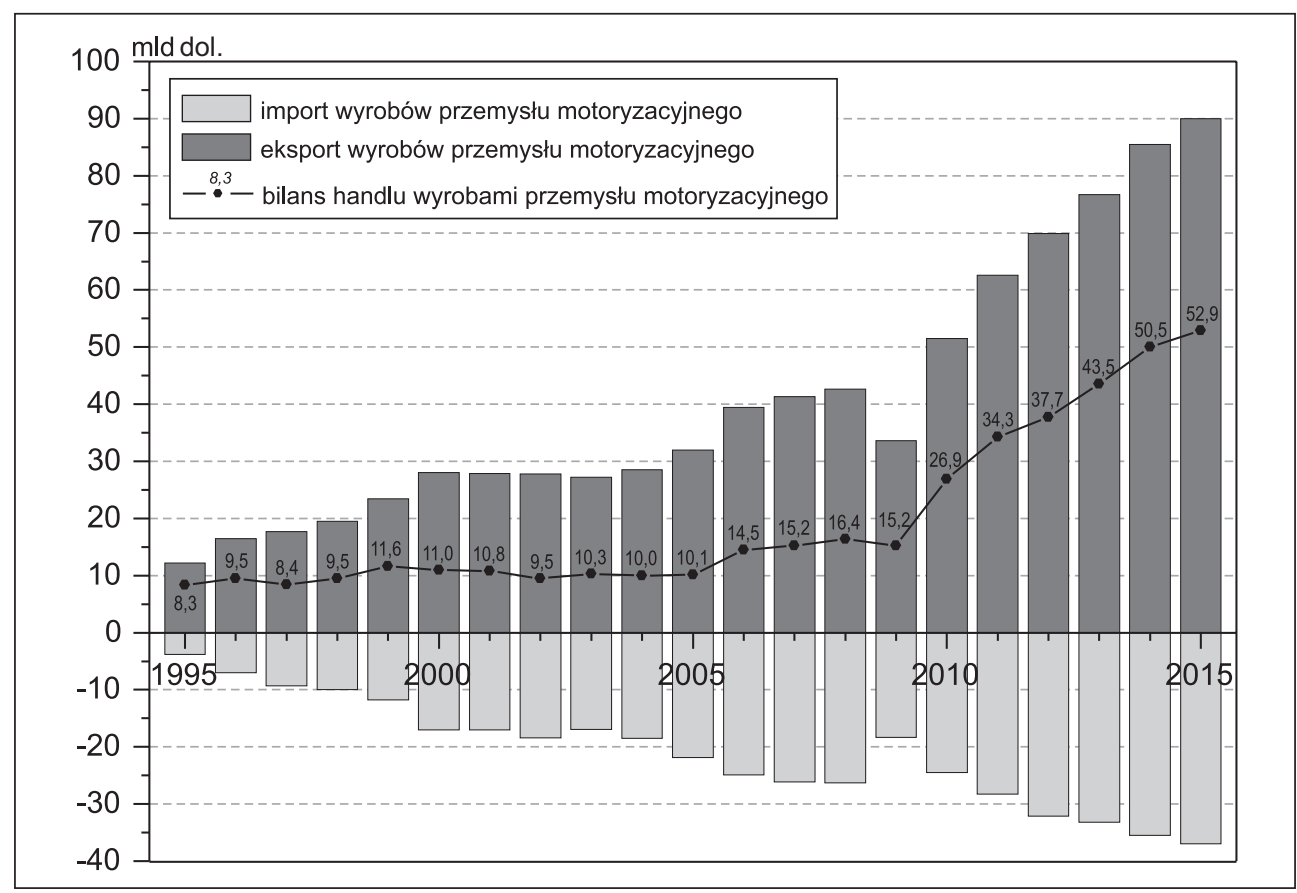

Źródło: opracowanie własne na bazie danych UNCTAD (2016)

Warto zwrócić uwagę na gwałtowny wzrost eksportu wyrobów motoryzacyjnych po kryzysowym 2009 roku. Wiązało się to z nowymi inwestycjami i dalszym przenoszeniem do Meksyku działalności produkcyjnej z Kanady i USA. Ponadto na wejście do tego kraju zdecydowały się nowe koncerny rozwijające produkcję eksportową na rynek USA, a także innych państw. Coraz większą rolę w eksporcie odgrywają też części i podzespoły, gdyż o ile amerykańskie koncerny nie decydują się przenieść całkowicie finalnej produkcji samochodów, jednak aby obniżyć jej koszty, starają się coraz więcej części i podzespołów wytwarzać w Meksyku (Wójtowicz, 2015; The Mexican Automotive Industry..., 2016).

W eksporcie wyrobów przemysłu środków transportu najważniejszą rolę odgrywają stany leżące wzdłuż granicy z USA, wśród których dominują: Coahuila, Nuevo Leon i Chihuahua. W 2014 roku wartość eksportu z tych trzech stanów wyniosła ponad 45 mld dol., co stanowiło 35,6\% ogólnej wartości eksportu tego sektora, a udział wszystkich sześciu przygranicznych stanów przekraczał 50,2\%. Znacząco zwiększył się także eksportu wyrobów przemysłu środków transportu z regionu Bajío, którego wartość w latach 2007-2014 wzrosła z 13,8 mld do 33,3 mld dol., co zwiększyło udział tego regionu z 22,6\% do 26,3\%. Najważniejszą rolę w tym regionie zaczęły odgrywać stany Guanajuato, Aguascalientes, San Luis Potosi i Queretaro, dostarczające blisko 91\% jego ogólnej wartości eksportu (ryc. 5).

W regionie centralnym również odnotowano wzrost wielkości eksportu wyrobów przemysłu środków transportu, z 12,9 mld dol. w 2007 roku do 27,1 mld dol. w 2014 roku. Najważniejszą rolę w tym regionie odegrały stany Meksyk i Puebla, z których 
Ryc. 5. Zmiana wartości eksportu wyrobów przemysłu środków transportu w latach 2007-2014

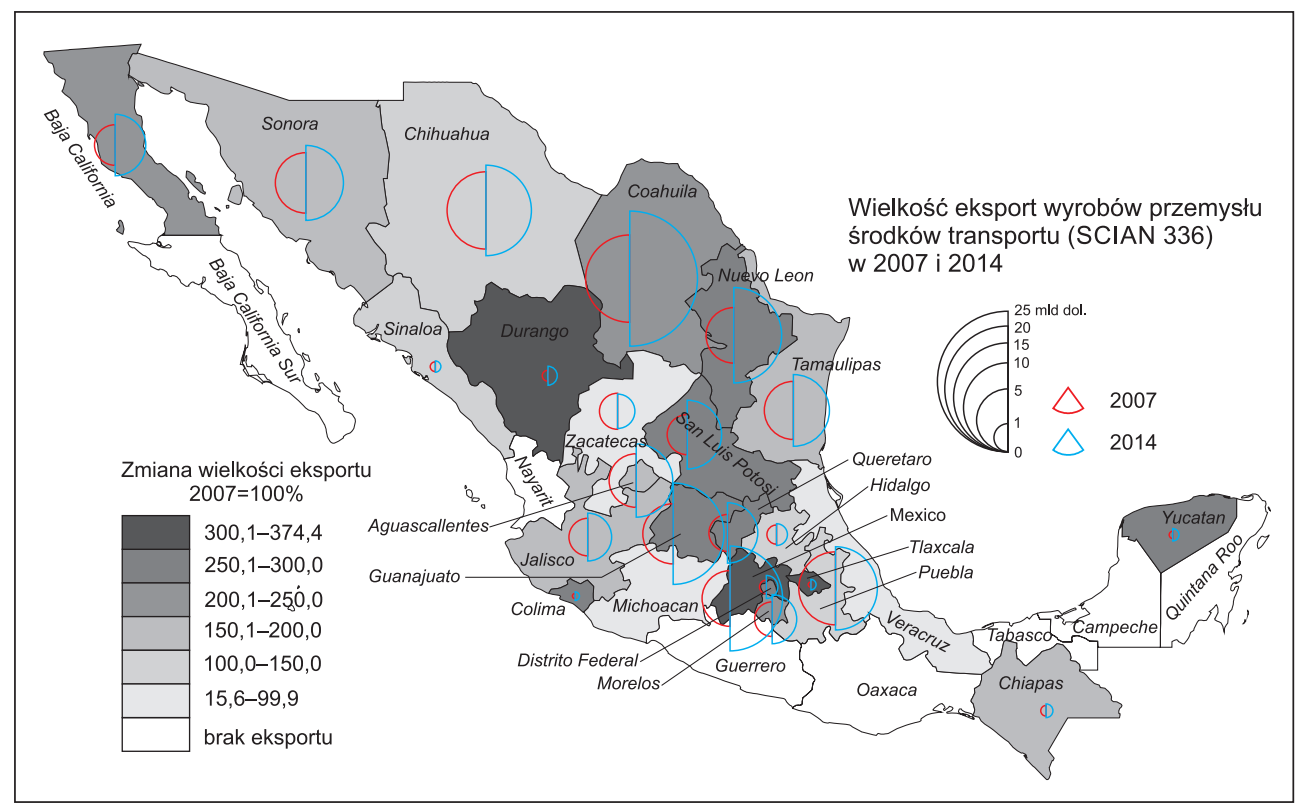

Źródło: opracowanie własne na podstawie Grupo de Trabajo de Estadísticas de Comercio Exterior, integrado por el Banco de México (2014)

wartość eksportu sięgnęła w 2014 roku aż 22,7 mld dol. Warto zwrócić uwagę, iż największy wzrost eksportu w ostatnich latach odnotował stan Meksyk (z 3,9 mld do 13,9 mld dol.), co przesunęło go na drugie miejsce w kraju po stanie Coahuila (ryc. 5). Może on posłużyć za bardzo dobry przekład udanej transformacji przemysłu samochodowego - od nieefektywnego i przestarzałego technologicznie, nastawionego na rynek wewnętrzny, do wysoce konkurencyjnego i nowoczesnego, nastawionego głównie na eksport (Carbajal Suárez, 2012).

\section{PODSUMOWANIE}

Przeprowadzone badania wskazują, iż przemysł samochodowy po reformach przeprowadzonych na przełomie lat osiemdziesiątych i dziewięćdziesiątych XX wieku stał się ważnym sektorem napędzającym rozwój gospodarczy Meksyku. W latach 1985-2014 sektor ten ponad czterokrotnie zwiększył swoje zatrudnienie, z niecałych 146 tys. do ponad 588 tys. osób. Przy czym temu wzrostowi towarzyszyło znaczne przesunięcie zatrudnienia w kierunku granicy z USA, postępujące wraz z zacieśnianiem współpracy w ramach NAFTA. Do ponad 6\% w 2014 roku wzrósł także udział przemysłu motoryzacyjnego w tworzeniu wartości dodanej brutto Meksyku. W 2015 roku sektor ten wytwarzał 3\% PKB i aż 18\% PKB przemysłu przetwórczego Meksyku. W latach 19992015 wchłonął inwestycje zagraniczne o wartości 43,8 mld dol., co stanowiło ponad 10\% ogólnego napływu BIZ do Meksyku.

Wzrostowi zatrudnienia i produkcji towarzyszył także dynamiczny wzrost wartości eksportu wyrobów przemysłu motoryzacyjnego, którego zdecydowana większość trafia na rynek USA. Od wejścia do NAFTA sektor ten notuje dodatni bilans wymiany 
handlowej przekraczający w ostatnich latach 50 mld dol., co sprawia, iż obok eksportu ropy naftowej jest on głównym źródłem dewiz, znacznie zmniejszających ujemny bilans handlowy kraju.

Rozwijający się i unowocześniający przemysł samochodowy jest również źródłem innowacji i efektów spin-off w meksykańskiej gospodarce, co przyczynia się do modernizacji kooperujących z nim przedsiębiorstw (Contreras, Carrillo, Alonso, 2012). Zmiana polityki względem tego sektora, z promującej produkcję na rynek wewnętrzny, która funkcjonowała do lat osiemdziesiątych XX wieku, na produkcję eksportową, zapoczątkowaną na przełomie lat osiemdziesiątych i dziewięćdziesiątych XX wieku, uchroniła ten sektor przed popadnięciem w jeszcze głębsze zacofanie technologiczne i marginalizację. Zapewniła także napływ nowych inwestycji i modernizację istniejących zakładów, co sprawiło, iż sektor ten nie tylko się dynamicznie rozwinął, ale także osiągnął międzynarodową konkurencyjność i znaczenie w skali regionalnej i globalnej.

Oczywiście sukces ten udało się osiągnąć nie tylko w wyniku prowadzonej przez rząd polityki, ale także dzięki udanemu sprzężeniu odpowiednich działań rządu ze strategiami globalnymi międzynarodowych koncernów samochodowych oraz postępującą integracją w ramach NAFTA. Splot tych czynników zaowocował pozytywnym sprzężeniem zapewniającym dynamiczny wzrost tego sektora, który w świetle dalszych deklaracji inwestycyjnych kolejnych koncernów będzie kontynuowany w nadchodzących latach (The Mexican Automotive Industry..., 2016). Pozwala to stwierdzić, iż sektor ten będzie odgrywał coraz istotniejszą rolę w rozwoju społeczno-gospodarczym Meksyku, zapewniając nie tylko coraz większą liczbę relatywnie dobrze płatnych miejsc pracy, ale przyczyniając się także do wzrostu wpływów podatkowych w stanach, w których zlokalizowane są jego zakłady, oraz wpływów dewizowych, będących efektem rosnącego eksportu.

\section{Literatura \\ References}

Acemoglu, D., Robinson, J.A. (2014). Dlaczego narody przegrywają. Źródła władzy pomyślności i ubóstwa. Poznań: Wydawnictwo Zysk i S-ka.

Altshuler, A., Anderson, M., Jones, D., Roos, D., Womack, J. (1986). The Future of the Automobile. The Report of MIT's International Automobile Program. Cambridge: MIT Press.

Bennett, D., Sharpe, K. (1984). Agenda Setting and Bargaining Power: The Mexican State vesus Transnational Automobile Corporations. W: R. Kronish, K.S. Mericle (red.). The Political Economy of the Latin American Motor Vehicle Industry, Cambridge-London: MIT Press, 195-229.

Bennett, D., Sharpe, K. (1985). Transnational Corporations versus the State. The Political Economy of the Mexican Auto Industry. Princeton: Princeton University Press.

Carbajal Suárez, Y. (2012). El sector automotriz en el Estado de México. Condiciones y retos de la cadena productiva. Paradigma económico, 4(2), 29-59.

Carrillo, J. (1991). Restructuración en la industria automotriz en México. Estudios Sociológicos, 9(27), 483-525.

Carrillo, J. (1997). Maquiladoras automotrices en México: Clusters y competencias de alto nivel. W: M. Novick, M. Gallart (red.). Competitividad, redes productivas y competencias laborales. Montevideo: OIT/CINTERFORD/Red Educación y Trabajo, 193-234.

Carrillo, J. (2000) The integration of the Mexican Automobile Industry to the USA: between polices and corporate strategies. Actes du GERPISA, 28, 55-77. 
Carrillo, J. (2004). NAFTA: The Process of Regional Integration of Motor Vehicle Production. W: J. Carrillo, Y. Lung, R. van Tulder (red.). Cars, Carriers of Regionalism? Houndmills-New York: Palgrave Macmillan, 104-117.

Carrillo, J., Hualde, A., Quintero, C. (2005). Maquiladoras en México. Breve recorrido histórico. Comercio Exterior, 55(1), 30-42.

Censos Económicos 1999 (1999). Instituto Nacional de Estadística y Geografía - INEGI, Mexico D.F. Pozyskano z http://www.inegi.org.mx/est/contenidos/proyectos/ce/ce1999/default.aspx

Censos Económicos 2009 (2009). Instituto Nacional de Estadística y Geografía - INEGI, Mexico D.F. Pozyskano z http://www.inegi.org.mx/est/contenidos/ espanol/proyectos/censos/ ce2009/default.asp?s=est\&c=14220

Censos Económicos 2014 (2014). Instituto Nacional de Estadística y Geografía - INEGI, Mexico D.F. Pozyskano z http://www.inegi.org.mx/est/contenidos/proyectos/accesomicrodatos/ ce2014/default.aspx

Contreras, O.F., Carrillo, J., Alonso, J. (2012). Local Entrepreneurship within Global Value Chains: A Case Study in the Mexican Automotive Industry. World Development, 40(5), 1013-1023.

Covarrubias, A.V. (2011). The Mexican Auto Industry: From Crisis to Greater Region-centric Influence. Norteamerica, 6(2), 115-155.

Czerny, M. (1994). Restrukturyzacja przemysłu i rozwój regionalny Meksyku. Warszawa: Centrum Studiów Latynoamerykańskich Uniwersytetu Warszawskiego.

Dorocki, S., Brzegowy, P. (2014). The maquiladora industry impact on the social and economic situation in Mexico in the era of globalization. W: M. Wójtowicz, A. Winiarczyk-Raźniak (red.). Environmental and socio-economic transformations in developing areas as the effect of globalization. Kraków: Wydawnictwo Naukowe Uniwersytetu Pedagogicznego, 93-110.

Encuesta Anual de la Industria Manufacturera (2013). Instituto Nacional de Estadística y Geografía - INEGI, Mexico D.F. Pozyskano z http://www.inegi.org.mx/sistemas/bie/default.aspx

Estadística oficial de los flujos de IED hacia México (2016). Secretaría de Economía, Mexico D.F. Pozyskano z http://www.economia.gob.mx/comunidad-negocios/competitividad-normatividad/inversion-extranjera-directa/estadistica-oficial-de-ied-en-mexico

Galbraith, J.K. (1973). Społeczeństwo dobrobytu państwo przemysłowe. Warszawa: Państwowy Instytut Wydawniczy.

Grupo de Trabajo de Estadísticas de Comercio Exterior, integrado por el Banco de México (2014). Instituto Nacional de Estadística y Geografía - INEGI, Mexico D.F. Pozyskano z http://www. inegi.org.mx/sistemas/bie/default.aspx

Holmes, J. (1993). From three industries to one: Towards an Integrated North American Automobile Industry. W: M. Appel Molot (red.). Driving continentally. National Policies and the North American Auto Industry. Ottawa: Carleton University Press, 23-61.

Juárez, N.H. (2005). Puebla, región anfitriona. Volkswagen, empresa lider. Un agrupamiento automotriz. W: H. Núñez Juáres, A. Lara Rivero, C. Bueno (red.). El auto global: Desarollo, competencia y cooperación en la industria del automóvil. Puebla: Benemeríta Universidad Autonóma de Puebla, Universidad Autonóma Metropolitana - Xochimilco, Universidad Iberoamericana Ciudad de México, Consejo Nacional de Ciencia y Tecnología, 169-207.

La industria automotriz en Mexico edicción 1994 (1994). Instituto Nacional de Estadística y Geografía - INEGI, Aguascalientes.

La industria automotriz en Mexico edicción 1998 (1998). Instituto Nacional de Estadística y Geografía - INEGI, Aguascalientes.

Łasak, P. (2013). Procesy umiędzynarodowienia przemysłu samochodowego. Rola rynków wschodzacych. Kraków: Wydawnictwo Uniwersytetu Jagiellońskiego.

Miranda, A.V. (2007). La industria automotriz en México. Antecedentes, situación actual y perspectivas. Contaduría y Administración, 221, 211-248.

Moreno-Brid, J.C. (1996). Mexico's auto industry after NAFTA: a successful experience in restructuring? Working Paper. The Helen Kellogg Institute for International Studies, 232.

Moreno-Brid, J.C., Ros, J. (2009). Development and Growth in the Mexican Economy: A Historical Perspective. New York: Oxford University Press. 
Moreno-Brid, J.C., Santamaria, J., Rivas Valdivia, J.C. (2005). Industrialization and Economic Growth in Mexico after NAFTA: The Road Travelled. Development and Change, 36(6), 10951119.

Mortimore, M. (1995). Transforming sitting ducks into flying geese: the Mexican automobile industry. Santiago: Economic Commission for Latin America and the Caribbean.

Shapiro, H. (1993). The determinants of trade and investment flows in LDC auto industries: The cases of Brazil and Mexico. W: M. Appel Molot (red.). Driving continentally. National Policies and the North American Auto Industry. Ottawa: Carleton University Press, 101-134.

Taylor, G. (1993). Strategic manpower policies and international competitiveness: the case of Mexico. W: M. Appel Molot (red.). Driving continentally. National Policies and the North American Auto Industry. Ottawa: Carleton University Press, 231-253.

The Mexican Automotive Industry: Current Situation, Challenges And Opportunities (2016). Ministry of Economy, ProMéxico Trade and Investment, Business Intelligence Unit, Mexico D.F. Pozyskano z http://www.promexico.mx/documentos/biblioteca/the-mexican-automotive-industry.pdf

UNCTAD (2016). Trade structure by partner, product or service-category. Pozyskano z http:// unctadstat.unctad.org/wds/ReportFolders/reportFolders.aspx

Unger, K. (1991). The Automotive Industry: Technological Change and Sourcing from Mexico. North American Review of Economics and Finance, 2(2), 109-128.

Womack, J.P., Jones, D.T., Roos, D. (2007). Maszyna która zmieniła świat. Wrocław: ProdPress. com.

Wójtowicz, M. (2011). Wpływ światowego kryzysu gospodarczego na brazylijski i meksykański przemysł samochodowy. Prace Komisji Geografii Przemysłu Polskiego Towarzystwa Geograficznego, 17, 129-143.

Wójtowicz, M. (2012). Rozwój i przekształcenia przemysłu samochodowego w Brazylii i Meksyku na przełomie XX i XXI wieku. W: M. Drgas, J. Knopek (red.). Gospodarcze problemy Ameryki Łacińskiej. Toruń: Wydawnictwo Adam Marszałek, 161-193.

Wójtowicz, M. (2015). Przekształcenia przestrzennej struktury meksykańskiego przemysłu samochodowego pod wpływem BIZ. Prace Komisji Geografii Przemysłu Polskiego Towarzystwa Geograficznego, 29(1), 7-26.

Wójtowicz, M., Rachwał, T. (2014). Globalization and New Centers of Automotive Manufacturing the Case of Brazil, Mexico, and Central Europe. Prace Komisji Geografii Przemysłu Polskiego Towarzystwa Geograficznego, 25, 81-107.

Mirosław Wójtowicz, dr nauk o Ziemi w zakresie geografii (specjalność geografia społeczno-ekonomiczna), adiunkt w Zakładzie Geografii Społeczno-Ekonomicznej Uniwersytetu Pedagogicznego w Krakowie. Jego zainteresowania badawcze koncentrują się wokół zagadnień procesów urbanizacji oraz industrializacji w Ameryce Łacińskiej, ze szczególnym uwzględnieniem Argentyny, Brazylii i Meksyku.

Mirosław Wójtowicz, Ph.D. in Earth Sciences in the field of Geography (specialization in Socio-Economic Geography), associate professor in the Department of Socio-Economic Geography at the Pedagogical University of Cracow. His research interests focus on issues of urbanization and industrialization process in Latin America, with particular emphasis on Argentina, Brazil and Mexico.

\section{Adres/address:}

Uniwersytet Pedagogiczny w Krakowie

Instytut Geografii

Zakład Geografii Społeczno-Ekonomicznej

ul. Podchorążych 2, 30-084 Kraków, Polska

e-mail: mwojt@up.krakow.pl 